\title{
Intra-atrial course of the right coronary artery: depiction of a potentially hazardous entity on dual-source CT
}

\author{
Kartik P Ganga, ${ }^{\ominus}$ Vineeta Ojha, ${ }^{\oplus}$ Manish Shaw, Sanjeev Kumar
}

Department of Cardiovascular Radiology and Endovascular Interventions, All India Institute of Medical Sciences, New Delhi, India

\section{Correspondence to} Dr Vineeta Ojha, vineetao17@gmail.com

Accepted 6 January 2019

\section{DESCRIPTION}

A 45-year-old man presented in the outpatient clinic with occasional atypical chest pain. ECG was normal, and echocardiography did not reveal any wall motion abnormality. The patient was referred to us for CT angiography (CTA) to rule out coroslice dual source scanner (Siemens SOMATOM Force) revealed intracavitary course of the mid-segment of the right coronary artery (RCA) within the $4.5 \mathrm{~cm}$ with a normal epicardial course of the rest of the RCA (figure $1 \mathrm{~B}$, asterisk and figure $2 \mathrm{~A}-\mathrm{C}$ ). There was no significant coronary artery stenosis.

Anomalous intracavitary coronary arteries were first described by McAlpine in $1975 .{ }^{1}$ Previously considered to be extremely rare abnormality, it is increasingly being recognised as a commoner entity with advent of CT. A recent study evaluating 7847 coronary CTA studies estimated the prevalence of intracavitary RCA to be $0.36 \% .^{2}$ Though this incidentally detected anomaly seems to be unrelated to our patient's chest pain, it is important to know about this entity before various interventions. The procedures which put the intracavitary RCA under risk of inadvertent damage include: (1) those requiring catheter manipulation in RA such as angiography, central venous catheter and pacemaker placement; (2) electrophysiological studies-during electrode placement, trans-septal puncture for LA access, RF ablation of arrhythmias; (3) CABG-during coronary localisation and grafting; (4) open heart surgery-during IVC/coronary sinus cannulation, dissection of target vessel
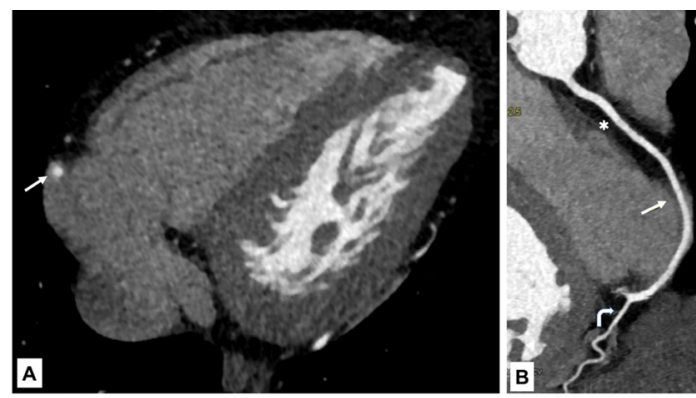

Limited 2019. No commercia re-use. See rights and permissions. Published by BMJ.

To cite: Ganga KP, Ojha V, Shaw $\mathrm{M}$, et al. BMJ Case Rep 2019:12:e228345. doi: $10.1136 /$ bcr-2018228345

(A) Axial CT image showing the intra-atrat
course of the right coronary artery (RCA) (arrow). (B) Curved multiplanar image showing the proximal RCA surrounded by epicardial fat (asterisk), the intra-atrial course of mid RCA for $4.5 \mathrm{~cm}$ (arrow) and the normal nary artery disease. The CTA, done on $192(\times 2)$ right atrium (RA) (figure 1A, arrow) for a length of
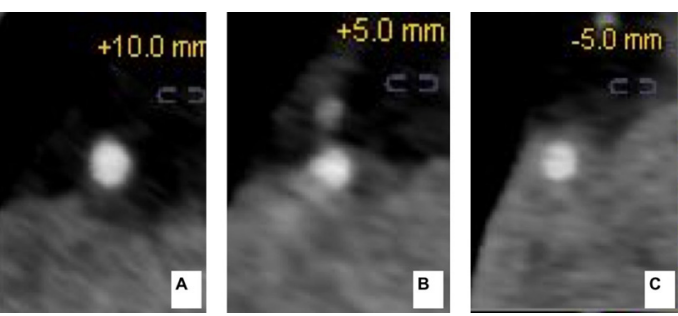

Figure 2 True cross-sectional images of the RCA at (A) proximal to the intra-atrial segment showing showing the RCA completely surrounded by epicardial fat. (B) At the level of arrow in 1B showing RCA entering into the right atrium (RA) and (C) intra-atrial segment of RCA which is surrounded by blood in RA.

and so on. CTA proves to be extremely helpful to forewarn the interventionist/surgeon of the presence of this entity before planning such procedures to avoid catastrophic damage to the coronary artery, thereby preventing myocardial ischaemia on table. $^{3}$

\section{Learning points}

- Intra-atrial course of the right coronary artery (RCA) is a rare variant anomaly.

- This anomalous course of the RCA puts it at risk during cardiac interventions and can result in myocardial ischaemia on table.

- It is imperative for the radiologist to diagnose and document this on the report so that necessary precautions can be taken during interventional procedures or during surgery.

Acknowledgements The surname of the patient is same as one of the coauthors, but the patient is not related to the coauthor in anyway.

Contributors Dr KPG contributed to the planning, data collection, preparation, design and final approval of this manuscript. Dr VO contributed to the preparation, editing, data interpretation and design of the manuscript. Dr MS contributed to the preparation, editing and approval of the manuscript. Dr SK contributed to the planning, editing and final approval of the manuscript.

Funding The authors have not declared a specific grant for this research from any funding agency in the public, commercial or not-for-profit sectors. epicardial course of distal RCA branches (bent arrow).
Competing interests None declared.

Patient consent for publication Obtained.

Provenance and peer review Not commissioned; externally peer reviewed. 


\section{Images in...}

\section{REFERENCES}

1 McAlpine WA. Heart and Coronary Arteries. New York: Springer-Verlag, 1975.

by coronary computed tomography angiography. J Am Coll Cardiol 2017;69:1437.

2 Buckley CM, Rosamond T, Hegde SR, et al. The intracavitary coronary artery: a rare anomaly with implications for invasive cardiac procedures - demonstration

3 Zalamea RM, Entrikin DW, Wannenburg T, et al. Anomalous intracavitary right coronary artery shown by cardiac CT: a potential hazard to be aware of before various interventions. J Cardiovasc Comput Tomogr 2009;3:57-61.

Copyright 2019 BMJ Publishing Group. All rights reserved. For permission to reuse any of this content visit https://www.bmj.com/company/products-services/rights-and-licensing/permissions/

BMJ Case Report Fellows may re-use this article for personal use and teaching without any further permission.

Become a Fellow of BMJ Case Reports today and you can:

- Submit as many cases as you like

- Enjoy fast sympathetic peer review and rapid publication of accepted articles

- Access all the published articles

- Re-use any of the published material for personal use and teaching without further permission

For information on Institutional Fellowships contact consortiasales@bmjgroup.com

Visit casereports.bmj.com for more articles like this and to become a Fellow 